\title{
The Analysis of Classroom Teaching Design of Life Education in Colleges and Universities
}

\author{
Yinchun Luo \\ China West Normal University, Nanchong Sichuan, PRC \\ Logistics Department, China West Normal University,
}

No. 1 Shi Da Road, Nanchong, 637009, Sichuan, China

Keywords: Colleges and universities; Life education; Classroom teaching

\begin{abstract}
Life education is the core content of College Students' mental health education, which is the basis for college students of leading to a happy life. In this paper, we hackle how to do the classroom teaching design of life education in colleges and universities by analyzing three aspects about the design of teaching objectives, the choice of teaching content and the choice of teaching methods.

Health is the eternal topic of human beings, and the primary task of health is to let people's life be renewed, and therefore, life education becomes the cornerstone of leading college students to keep physical and mental health. The classroom teaching is the main position of life education for college students. To enable students to understand the hard-won life, have a profound understanding of life meaning, learn to cherish life, lead positive and optimistic attitude in the face of life, from where I am standing, university teachers need to use classroom teaching to the fullest, and from the following three aspects to do the design of classroom teaching.
\end{abstract}

\section{Specifying Life Education Task to form the Classroom Teaching Objectives}

The task of classroom teaching of life education in colleges and universities is learning to gain the understanding of life, cultivating students to have the attitude of cherishing life and the habit of loving life, teaching students how to create the value of life so as to realize the significance of life.

As a teacher, we must make clear and detailed teaching tasks in the classroom before teaching, in order to form the specific teaching objectives of this class. The classroom teaching of life education can be understood and set up from the following aspects:

Understanding of human evolution process and the birth of life process, appreciating and accepting various forms of life;

Understanding the meaning and value of life;

Establishing the attitude of treasuring life;

Mastering the methods and skills of caring life, developing a habit of loving life.

\section{Choosing Scientific and Appropriate Teaching Contents to Achieve the Teaching Objectives}

The realization of every specific objective must rely on the appropriate teaching contents. If we want to achieve some certain teaching objectives effectively, we should select the teaching contents scientifically and appropriately.

Firstly, teachers are ought to help students have a better understanding of biological knowledge through the review of the process of human evolution, and then teachers are ought to play a lot of pictures and videos for students to have an intuitive feeling of the birth of life. At last, teachers are ought to provide a lot of pictures about nature and human beings so that students can perceive the beauty of them and to feel the various forms of existence of life in nature. So it is the first teaching objective that can have a basis.

Secondly, teachers should make students learn the spirits that not yielding to the fate of some characters such as Hwaking, Zhang Haidi and the contributions for society and mankind by some people like Edison and Yuan Longping to perceive the meaning and value of life existence. What's 
more, teachers are ought to make students understand places that relating to the living, the old, the ill and the dead, such as nursing home, hospital and so on to guide students to have a deep thought of the meaning of birth and death.

Thirdly, teachers can explain the life probability for students so that they can have a feeling that life is not easy to own. At the same time, teachers can present many materials about the attitude of life of different people such as the comparison of the attitude of the college students who ignore the life and trample life and the attitude of fight against the disease of typical characters to make students to experience the pity of not cherishing the life and feel the shortness and preciousness of life. Because of that, teachers can let students have the desire to cherish life and establish an attitude to cherish life.

Finally, teachers are ought to make full use of adolescent education, psychological education, safety education, health education, thanksgiving education, environment education, anti-drug education, AIDS prevention education and legal education and many other special education forms to carry out efficient, flexible, and diverse life education activities to let students master the methods and skills about the life care, so that students will develop the habit of loving life.

\section{Using Rich and Effective Teaching Methods to Active Classroom Atmosphere}

A classroom teaching includes three links, namely course introduction, course teaching and course summary. Teachers in every link need to combine the university students' knowledge and learning characteristic and relate to the specific situation to use the different reasonable teaching methods. At the same time of the completion of teaching tasks, teachers should make the class more active.

\section{Course Introduction Stage}

The method of teacher introduction course has an important role in the whole classroom teaching, which greatly influences the students' interest in the teaching content and determines the effect of teaching. In the teaching of life education in colleges and universities, we can adopt the following methods:

Picture Appreciation Introduction Method. Teachers can through playing the pictures with music which are related to life (such as the beautiful nature scenery pictures) to let the students enjoy the pictures, at the same time, and feel the goodness of life, thus opening the understanding of life. Using this method, teachers should pay attention to selection of pictures, in line with the university student's psychological characteristic and the level of appreciation, at the same time, the background music and the pictures should demonstrate the thrust a good combination.

Story and Case Introduction Method. Teachers can show some stories and cases through video media to let the students to find process of discovery and understand the main idea of the story or the case in their watching, which is the course keynote. Teachers need to pay attention to the relevant stories and case materials which are not too long, as long as it is able to highlight the theme of life education.

Games and Activities Introduction Method. The teacher should lead the students to carry on the game or the activity which is related life experience to let the student in the activity to realize this curriculum the intention. This method is easy to arouse the students' interest and the classroom atmosphere will be active at the beginning. When using this method, the teacher needs to consider the complexity of the game or activity, pay attention to the class of controllability.

Problem Introduction Method. The teacher can enter a new class by asking the students to put forward the problem of life education, by using a problem directly into the subject, or multiple layers of the introduction of a number of issues. This method is monotonous so that teachers should pay more attention to the numbers and duration of questions and problems in using it in order to avoid the situation that there is silence or let students dislike the phenomenon.

\section{Course Teaching Stage}

The teaching of the course is the core of a class, which decides the success or failure of classroom teaching. I think teachers can adopt the following method in the classroom teaching:

Classroom Lecture Method. The classroom lecture method is the most conventional and traditional teaching method for teaching and it is also the most basic method in the teaching of 
knowledge. Students will know the value of life and have a deep understanding of life throu gh the oral teaching by teachers, and what's more important is that students will establish the correct outlook on life. In the process of teaching, teachers need to target different teaching objects and contents, using different oral expression form, in order to achieve the best lecture effect.

Story Sharing Method. In this kind of teaching method, teachers will let the students in the classroom to tell their own stories about aspects of life, learning, work and so on. Stories can be funny stories, sad stories or inspirational stories, etc. By sharing the life story, students can feel others' life of laughter, anger, sorrow and happiness. At the same time, students will be able to sum up his life bit by bit. In the classroom teaching, teachers can try to in spire students to share their life stories by sharing teachers' own stories so that to influence, affect and motivate students. What's more, it is a good way to narrow the distance between students and teachers and establish a relationship of mutual trust to form the resonance. Of course, this method needs to take the voluntary principle. Teachers should not let the students have a sense of reluctance, or teachers deliberately expose the pain of students' life.

Multimedia Teaching Method. Multimedia instruction is the combination use of a set of images, sounds, pictures, texts, animations, videos and other media. with illustrations, audio-visual superb, the combination of static and dynamic performance, multimedia teaching method is a mean for teachers to show the contents to students, using the extraordinary performance force to cross the time and space, which can enhance people's understanding and feelings of the abstract things and process, so the classroom teaching can get into a new realm. Life education in the classroom teaching, whether it is a colorful life picture, or an intuitive perceive of life process can use the multimedia technology and platform to have a more vivid and detailed presentation. Media teaching can provide a variety of methods for the presentation of life. Multimedia teaching method used by teachers to students provides a relaxed and rich learning atmosphere, and the multimedia teaching can improve students' self-learning ability, which can also improve the teacher-student communication and can stimulate students' interests to explore the life more efficiently. Teachers need to pay attention to the use of multimedia teaching method in the course of a class to ensure the appropriate amount, high quality, and the targeted, which is seen as the key to the success of the whole lesson.

In addition, according to the needs of the teaching content, in the course of teaching, teachers can use some appropriate case analysis, games, group discussions and other forms of learning for students.

\section{Classroom Summary Stage}

In order to make the classroom teaching more complete and to make the students have a deeper and systematic understanding of the contents and the main purpose of the whole class, summing up the class is indispensable. Summing up the class is a highly concentrated process and it presents class topics. Teachers can adopt various forms to complete, such as: teacher self summary, student summary or a sum up made by students and teachers together; the summary can also be a video, a poem, or a sentence saying.

In conclusion, any classroom teaching design should be based on the teaching objectives, and teachers should select the appropriate teaching contents, in line with the needs of students' psychology to achieve the core purpose of teaching to reach the best results. The teaching of life education in Colleges and universities is no exception as well. So all colleges and universities should be develop from their own actual situation, specify the teaching tasks to form clear teaching objectives, choose suitable contents to adapt to the characteristics of their own students, adopt a variety of effective teaching methods, and create the teaching ways to students' taste. Only in these ways can guide the students to form a correct understanding of outlook on life.

\section{References}

[1] Jiang Hai-yan. Life Education :New Problem in College Education[J].Heilongjiang Researches on Higher Education, 2005(3): 20 to 21.

[2] Zhao Jing. Discussing the Significance and Methods of Graduate Students Life 
Education[J].Science and Technology of West China,2010(19): 83 to 84, and 51.

[3] Liu Hui, Life education foundation for the healthy growth of [J], Chinese Book Review Monthly,2011(6): 9 to 13.

[4] Zhang Hongyan. The United States carry out the practice of life education and Its revelation [J], Beijing Education,2011(6): 78 to 80.

[5] He Xiaojie. Life education problems and Countermeasures of contemporary college students in China[D], Shandong Normal University, 2011

[6] Zhu Qinghua. The primary study on the classroom teaching of life education in primary and secondary schools [J], Mental Health Education of Primary and Middle Schools, 2012(7): 21 to 23

[7] Zhang Meiyun. Thinking about the design of life education curriculum [J]. Educational Science Research, 2006(3): 27 to 30.

[8] $\mathrm{Hu}$ Kun, the course and teaching method of College Students' life education [J]. New Curriculum Research, 2015(6):40 to 41. 